\title{
Occurrence and Characterization of a Phytophthora sp. Pathogenic to Asparagus (Asparagus officinalis) in Michigan
}

\author{
C. Saude, O. P. Hurtado-Gonzales, K. H. Lamour, and M. K. Hausbeck
}

First and fourth authors: Department of Plant Pathology, Michigan State University, East Lansing 48824-1311; and second and third authors: Department of Entomology and Plant Pathology, University of Tennessee, Knoxville 37996-4560.

Current address of first author: University of Guelph, Department of Plant Agriculture, Muck Research Station, ON, L0G 1J0, Canada. Accepted for publication 17 June 2008.

\begin{abstract}
Saude, C., Hurtado-Gonzales, O. P., Lamour, K. H., and Hausbeck, M. K. 2008. Occurrence and characterization of a Phytophthora sp. pathogenic to asparagus (Asparagus officinalis) in Michigan. Phytopathology 98: $1075-1083$.

A homothallic Phytophthora sp. was recovered from asparagus (Asparagus officinalis) spears, storage roots, crowns, and stems in northwest and central Michigan in 2004 and 2005. Isolates $(n=131)$ produced ovoid, nonpapillate, noncaducous sporangia $45 \mu \mathrm{m}$ long $\times 26 \mu \mathrm{m}$ wide

fragment length polymorphism analysis of 99 isolates revealed identical fingerprints, with 12 clearly resolved fragments present and no clearly resolved polymorphic fragments, suggesting a single clonal lineage. The internal transcribed spacer regions of representative isolates were homologous with a Phytophthora sp. isolated from diseased asparagus in France and a Phytophthora sp. from agave in Australia. Phylogenetic analysis supports the conclusion that the Phytophthora sp. isolated from asparagus in Michigan is a distinct species, and has been named Phytophthora asparagi.
\end{abstract} and amphigynous oospores of 25 to $30 \mu \mathrm{m}$ diameter. Mycelial growth was optimum at $25^{\circ} \mathrm{C}$ with no growth at 5 and $30^{\circ} \mathrm{C}$. All isolates were sensitive to $100 \mathrm{ppm}$ mefenoxam. Pathogenicity studies confirmed the ability of the isolates to infect asparagus as well as cucurbits. Amplified
Additional keywords: Fusarium crown and root rot, P. megasperma, spear rot.
Michigan ranks third nationally for fresh and processing asparagus (Asparagus officinalis), following California and Washington (3). In 2007, 10.7 million $\mathrm{kg}$ of asparagus spears were harvested from fields located in Mason and Oceana Counties in the northwest and Van Buren County in the southwest. Asparagus is a deep-rooted perennial crop that can have a production span of more than 15 years. In Michigan, asparagus production fields are established from 1-year-old crowns that are produced from seeds in nursery fields. Crowns consist of rhizomes and fleshy, fibrous roots. The thick and somewhat woody rhizomes are sites of nutrient and starch accumulation and contain buds that give rise to spears. The spears are edible, tender, succulent aerial stems with a prominent modified leaf. If not harvested, spears expand into extensively branched ferns with cladophylls, the asparagus true leaves (13).

Several diseases limit asparagus production $(4,14,19)$. Phytophthora spear and root rot is a significant problem in most asparagus growing areas in Europe (39), North America (4,50), Australia (10), and New Zealand (6). In the United States, the disease is most prevalent in warm climates, but has also been reported in cooler growing regions (14). Spear and root rot was first reported and described in California in 1938 and a Phytophthora sp. was identified as the causal agent (4). The disease was not extensively studied until the 1980 s, when 34 to $50 \%$ yield losses occurred in California due to spear rot in the field and postharvest disease development, caused predominantly by $P$. megasperma var. sojae and other Phytophthora spp. $(19,20)$.

Phytophthora spear and root rot varies among growing seasons and sites; the pathogen is highly favored by excessive rainfall and

Corresponding author: M. K. Hausbeck; E-mail address: hausbec1@msu.edu

doi:10.1094/PHYTO-98-10-1075

(C) 2008 The American Phytopathological Society poor soil drainage $(21,22,24)$. Disease symptoms include soft, water-soaked lesions on shoots slightly above or below the soil line. Under favorable conditions, lesions rapidly elongate and turn light brown in color resulting in shriveling and curved growth of the spear. Infected storage roots are initially firm but become water-soaked, and shrivel as lesions expand. Root mass and vigor can be reduced. Internal tissues of the infected crowns may be yellow to brown in color; however, these symptoms can also be attributed to Fusarium crown and root rot, caused by Fusarium oxysporum f. sp. asparagi (14).

$P$. megasperma Dreschsler has been associated with Phytophthora spear and root rot, but other Phytophthora spp., such as $P$. richardiae, $P$. cryptogea $(19,23)$, P. megasperma var. sojae $(2,5$, $6,16,17,19,28$ ), and $P$. cactorum (39) have also been identified from several asparagus production areas worldwide. Because morphological characteristics of different $P$. megasperma taxa can be indiscernible, molecular methods such as sequence analysis of various regions of the ribosomal DNA $(32,52)$, nuclear and mitochondrial DNA (27), and restriction fragment length polymorphisms (26), have been used to separate and further clarify the complex $P$. megasperma taxa. Based on molecular parameters, $P$. megasperma isolates have been sorted into nine groups, five of which are host-specific and four non-host-specific. Some isolates that were previously considered to be $P$. megasperma have been renamed as $P$. medicaginis from alfalfa (Medicago sativa), $P$. sojae from soybean (Glycine max), and P. trifolii from clover (Trifolium prateus) (30). In addition, host-specific Fraser fir (Abies fraseri) and asparagus groups of Phytophthora spp. have been determined, and are currently being studied and reclassified $(7,26)$. The non-host-specific Phytophthora spp. isolates are included in an undefined broad host range group (27).

In spring 2004, a spear and root rot was observed in several asparagus fields in Oceana, Ingham, and Van Buren Counties, Michigan (45). A Phytophthora sp. with morphological charac- 
teristics similar to $P$. megasperma was consistently isolated from spears, roots, crowns, and stems of symptomatic plants. The complexity of the taxonomy of this Phytophthora group raises the following questions. Which Phytophthora spp. infect asparagus in Michigan? Are the isolates specific to asparagus or can they infect other crops commonly grown in the asparagus production regions? Answers to these questions will assist in defining strategies necessary to manage Phytophthora spear and root rot of asparagus in this significant asparagus-producing region of the United States. The objective of this study was to describe the phenotypic and genotypic diversity of the Phytophthora species causing disease on asparagus in Michigan.

\section{MATERIALS AND METHODS}

Field sampling and symptoms. Asparagus spears and crowns growing in fields located in northwest (29 fields), central (2 fields), and southwest (10 fields) Michigan were sampled for Phytophthora spp. in the spring of 2004 and 2005. In the northwest, fields were located near the Asparagus Research Station in Hart, an area with mostly Benona sandy soils. In the central region, samples were collected from fields at the Michigan State University Plant Pathology Research Farm in East Lansing. These fields were characterized as having Spinks loamy sandy soils. Fields in the southwest portion of the state were primarily Oshtemo sandy soils and were located near the Michigan State University Southwest Michigan Research and Extension Center in Benton Harbor. Average monthly minimum and maximum temperatures and total rainfall during each growing season (May to October) for 2004 and 2005 were obtained from the Michigan Automated Weather Network in Hart (northwest Michigan), East Lansing (central Michigan), and Benton Harbor (southwest Michigan).

In 2004 and 2005, a minimum sample size of 1,500 asparagus crowns/roots and 1,000 spears were collected from fields and a crown storage facility (2004 only) based on symptoms characteristic of Phytophthora spear and root rot.

Pathogen isolation and maintenance. Phytophthora isolates were recovered from the samples by excising small sections of tissue $(5 \times 5 \mathrm{~mm})$ from the lesion margins and placing them onto BARP- (25 ppm of benomyl, $100 \mathrm{ppm}$ of ampicillin, $30 \mathrm{ppm}$ of rifampicin, and $100 \mathrm{ppm}$ of pentachloronitrobenzene) amended V8 juice agar ( $840 \mathrm{ml}$ of distilled water, $163 \mathrm{ml}$ of unclarified V8 juice, $3 \mathrm{~g}$ of $\mathrm{CaCO}_{3}$, and $16 \mathrm{~g}$ of agar) at $25^{\circ} \mathrm{C}$ for 5 to 7 days under laboratory lighting. Single sporangia were transferred to AR (100 ppm of ampicillin and $30 \mathrm{ppm}$ of rifampicin) amended unclarified V8 juice agar (AR-V8) to obtain axenic cultures. Axenic cultures were maintained on AR-V8 plates at 23 to $25^{\circ} \mathrm{C}$ and transferred every 2 months. For long-term storage, isolates were placed into sterile microcentrifuge tubes containing two 7-mm mycelial plugs cut from the edge of actively growing axenic cultures, two sterile hemp seeds and $1 \mathrm{ml}$ of sterile distilled water. Long-term isolates were incubated for 2 to 3 weeks at 23 to $25^{\circ} \mathrm{C}$, and then stored in an unlit incubator at $15^{\circ} \mathrm{C}$.

Colony and spore morphology. Phytophthora isolates were identified by comparing colony growth patterns and morphological features of sporangia, oospores, and hyphae $(15,51)$. For evaluation of colony morphology, isolates were grown for 7 days on AR-V8 juice agar plates $(100 \times 15 \mathrm{~mm})$ and incubated at 23 to $25^{\circ} \mathrm{C}$. Sporangia and oospores were produced on dilute V8 juice agar (40 ml of V8 juice, $1.5 \mathrm{~g}$ of $\mathrm{CaCO}_{3}$, and $960 \mathrm{ml}$ of distilled water). The morphology of sporangia and oospores was assessed by measuring the length and breadth of 50 sporangia and the diameter of 50 oospores from 48 representative isolates (35 recovered in 2004 and 13 recovered in 2005) using light microscopy $(\times 200)$.

Effect of temperature on mycelial growth. To determine the isolates' optimum temperature for growth, AR-V8 juice agar plates were inoculated with 7-mm diameter mycelial plugs from the edge of actively growing cultures. Plates were incubated in the dark using PTC-1 Peltier-effect temperature cabinets (Sable Systems International, Las Vegas, NV) at 5, 10, 15, 20, 25, and $30^{\circ} \mathrm{C}$. Four plates per isolate per temperature were used. Growth rates were assessed 3 and 7 days after inoculation by measuring colony diameters with mycelial plugs subtracted. The test was conducted twice and data from both experiments averaged. Data were analyzed using Proc Mix of SAS (SAS Institute, Cary, NC) with Tukey means separation $(P=0.05)$ used to compare colony diameters of isolates.

Mefenoxam sensitivity. Isolates were screened for sensitivity to the fungicide mefenoxam (Ridomil Gold 4EC, Syngenta, Greensboro, NC) by comparing the growth rate of mycelial plugs placed at the center of mefenoxam-amended V8 juice agar plates with the growth on unamended plates. Mefenoxam was suspended in sterile distilled water and added to medium cooled to $50^{\circ} \mathrm{C}$. For each isolate, four $100 \mathrm{ppm}$ and two $0 \mathrm{ppm}$ mefenoxamamended plates were inoculated with a 7-mm mycelial plug from the edge of actively growing 5-day-old cultures and incubated at $25^{\circ} \mathrm{C}$ under laboratory lighting. Colony diameters were measured 5 days after inoculation. Percent growth of an isolate on amended medium was calculated by subtracting the inoculum plug diameter $(7 \mathrm{~mm})$ from the diameter of each colony and dividing by the diameter of the nonamended control. Isolates were assigned mefenoxam sensitivity ratings based on the percent growth of the control. Isolates were scored as sensitive (S) when percent growth was $<30 \%$, intermediate sensitive (IS) when percent growth was 30 to $90 \%$, and resistant (R) when percent growth was $>90 \%$ (36).

Pathogenicity on asparagus spears. Koch's postulates were fulfilled to establish the pathogenicity of Phytophthora sp. The pathogenicity of Phytophthora sp. isolated from asparagus was assessed on 15-cm long, 2- to 4-day-old 'Jersey Knight' asparagus spears. Spears were washed with dish soap in tap water, surface disinfested with sodium hypochlorite $(5 \%)$ for $3 \mathrm{~min}$, rinsed with sterile distilled water, and air-dried at room temperature. The middle of the spears was surface wounded with a needle sterilized with $95 \%$ ethanol. The wound was covered with a 7-mm mycelial plug of a Phytophthora isolate from the edge of actively growing 5-day-old cultures on AR-V8 juice agar. Plugs were placed mycelial side down on spears and covered with sterile $1.5-\mathrm{cm}$ microcentrifuge tube caps sealed to the plant surface with petroleum jelly. Control spears were inoculated with sterile 7-mm plugs of AR-V8 agar. Five spears were inoculated per isolate and a total of 115 isolates were evaluated. Inoculated spears were placed in aluminum trays with wet paper towels (to maintain high humidity) and covered with plastic wrap. Trays were incubated at 23 to $25^{\circ} \mathrm{C}$ on laboratory bench tops under ambient lighting, and lesion length was measured 7 days after inoculation. This evaluation was conducted twice. A Student-Newman-Keuls means separation test $(P=0.05)$ was used to compare lesion length on spears inoculated with Phytophthora isolates with the noninoculated control.

Pathogenicity on asparagus, soybean, alfalfa, and red clover seedlings. Pathogenicity of Phytophthora isolate C009 and P. sojae isolate P23 (provided by P. Hart, Michigan State University) was tested on asparagus seedlings of cultivars Jersey Giant and Mary Washington, on soybean (Glycine max) seedlings of cultivar Williams, and on alfalfa (Medicago sativa) and red clover (Trifolium sp.) seedlings in the greenhouse. Plant inoculations were carried out using a method adapted from Falloon (18). Asparagus seeds were disinfested according to Damicone et al. (11). Soybean, alfalfa, and red clover seeds were not disinfested. All seeds were planted in flats filled with soilless media (Baccto Professional Planting Mix, Michigan Peat Company, Houston, TX) and allowed to grow for 2 weeks on greenhouse benches. Inoculum was prepared by culturing both Phytophthora sp. and $P$. sojae isolates on $\mathrm{AR}-\mathrm{V} 8$ agar for 8 to 10 days at 23 to $25^{\circ} \mathrm{C}$ under ambient lighting. Two $1-\mathrm{cm}$ mycelial plugs were placed into flasks 
containing autoclaved oat seeds, and allowed to grow and colonize the seeds for 3 weeks. Inoculum $(150 \mathrm{~g})$ was mixed into $4 \mathrm{~kg}$ of an autoclaved mix (50:50) of sand and soilless media. Pots $(8.9 \times$ $6.7 \mathrm{~cm}$ ) were filled with the infested sand/soilless mix and one seedling of each of the four plant species were transplanted per pot. Controls contained a mixture of autoclaved oat seeds and sand/soilless mix and were placed on trays separated from infested pots. Eight plants of each cultivar were used. Plants growing in pots infested with the same Phytophthora isolate were randomly placed on trays without drainage holes and flooded with approximately $4 \mathrm{~cm}$ of water for 3 days. On the third day, pots were transferred to trays with drainage holes and watered as needed. The numbers of wilted and dead plants were recorded weekly for 4 weeks and the test was conducted twice. Data were analyzed using PROC GLM of SAS and Student-Newman-Keuls means separation test $(P=0.05)$ to compare severity of disease on asparagus, soybean, alfalfa, and red clover seedlings.

Pathogenicity on cucurbit fruits. Twenty-five Phytophthora isolates were tested for pathogenicity on slicing and pickling cucumber (Cucumis sativus), yellow squash (Cucurbita moschata), zucchini (Cucurbita pepo), and acorn squash (Cucurbita sp.) fruits obtained from a local supplier. Fruits were washed with dish soap in tap water, surface disinfested with sodium hypochlorite $(5 \%)$ for $5 \mathrm{~min}$, rinsed with sterile water, and air-dried at room temperature. Fruits were wounded with a needle sterilized with 95\% ethanol. A 7-mm mycelial plug of each Phytophthora isolate was placed mycelial side down over the wounds, covered with a sterile $1.5-\mathrm{cm}$ microcentrifuge tube and sealed to the fruit surface with petroleum jelly. Wounded fruits inoculated with sterile ARV8 agar plugs were used as controls. Three fruits were inoculated per isolate. Inoculated fruits were incubated in aluminum trays containing wet paper towels, covered with plastic wrap, and maintained at 23 to $25^{\circ} \mathrm{C}$ on laboratory bench tops with ambient lighting. Lesion lengths were assessed 7 days after inoculation and the test was conducted twice. Data were analyzed using PROC GLM of SAS and Student-Newman-Keuls means separation test $(P=0.05)$ to compare lesion length on fruits inoculated with Phytophthora isolates with the noninoculated control.

DNA isolation and genotyping. Isolates were cultured and treated according to Lamour and Finley (35) for high throughput DNA isolation. Amplified fragment length polymorphism (AFLP) marker generation was carried out as described by Habera et al. (29). An overnight restriction-ligation reaction was carried out using $150 \mathrm{ng}$ of DNA in an $11-\mu \mathrm{l}$ volume format at room temperature. Restriction-ligation products were diluted to $200 \mu \mathrm{l}$ with $10 \mu \mathrm{M}$ Tris and a nonfluorescent pre-selective amplification was performed using primers Eco+0 and MseI+0. Adapter sequences were as described by Vos et al. (49). Ten microliters of the preselective amplification was run on a $1 \%$ agarose gel to confirm amplification and the remaining $10 \mu \mathrm{l}$ was diluted and used for subsequent selective amplification using primers $\operatorname{Eco}(\mathrm{AC})$ and $\mathrm{Mse}(\mathrm{CA})$. A second selective amplification using a fluorescentlabeled primer (Proligo, Boulder, $\mathrm{CO}$ ) for $\operatorname{Eco}(\mathrm{AC})$ and nonfluorescent primer for Mse(CA) (Integrated DNA Technologies, Skokie, IL) was performed. Fluorescent polymerase chain reaction (PCR) products were analyzed on a CEQ 8000 Genetic Analysis System (Beckman Coulter, Fullerton, CA) following the manufacturer's protocols.

Internal transcribed spacer (ITS) sequencing and phylogenetic analysis. Sequence for the ITS region was generated as described by Cooke et al. (7). PCR products were resolved on $1 \%$ agarose gel to insure a single PCR product and were then purified using Qiagen PCR clean up columns (Qiagen, Valencia, CA) following the manufacturer's instructions and diluted with $5 \mathrm{mM}$ Tris. The resulting amplicon was sequenced in both directions using an ABI3700 sequencer (Sequencing Facilities at the University of Tennessee). Sequences were checked for quality using Phred v2.3.1a software and visualized using Sequencher (Gene-
Codes, Ann Arbor, MI). The sequence was submitted to a BLASTn search (1) of the National Center for Biotechnology Information GenBank database. Results of the BLASTnquery from six additional Phytophthora spp. that exhibited the closest levels of similarity were also downloaded and included in the phylogenetic analysis. The following six species were included: $P$. cryptogea (L76538.1), P. drechsleri (L76547), P. gonapodyides (AY787027), $P$. megasperma (AY995359), $P$. humicola (AF266792), and P. inundata (AF266791.1). P. sojae (AF266769) was included as an outgroup. Sequences were aligned using CLUSTALW (48), exported as an NBRF file, and imported into MacClade v4.08. Minor insertions or deletions were adjusted visually within MacClade.

Maximum likelihood analyses. Phylogenetic trees were estimated under the maximum likelihood (ML) criterion implemented in phylogenetic analysis using parsimony (PAUP*) $4.0 \mathrm{~b} 10$ (47). Nucleotide substitution models for the molecular data set were selected using Modeltest 3.06 (42). An optimal ML tree was then created via heuristic searches of tree space using tree-bisection-reconnection (TBR) branch swapping in a random stepwise addition of taxa repeated 10 times. Node support was evaluated by nonparametric bootstrap resampling (25).

\section{RESULTS}

Field sampling and pathogen isolation. In 2004, dormant crowns held in bulk bins in cold storage prior to planting exhibited water-soaked lesions and/or shriveling, but the tissue was firm at the lesion site (Fig. 1A). Spears observed in the field exhibited a shepherd's crook symptom, with soft water-soaked lesions (Fig. 1B) and/or shriveling occurring slightly above or below the soil line (Fig. 1C and D). In 2005, water-soaked lesions were rarely observed on either spears or storage roots sampled from the field; necrotic lesions on storage roots and spears with a shepherd's crook were the most prevalent symptoms. In 2004, Phytophthora sp. was isolated from most of the asparagus plants sampled, primarily from symptomatic spears (Table 1). A total of 115 isolates were recovered; $48 \%$ of the isolates were from spears, $25 \%$ from storage roots, $14 \%$ from crowns, $8 \%$ from stems, and $5 \%$ from asparagus seedling stems (Table 1). The pathogen was not recovered from samples collected from fields located in the southwest region of Michigan, although the spears and fern exhibited shriveling, stunting, and a shepherd's crook symptom associated with Phytophthora infection. In 2005, hundreds of samples were collected from asparagus fields located in the three asparagus growing regions. Only 13 Phytophthora isolates were recovered from samples collected from two commercial asparagus fields in northwest Michigan. The pathogen was not recovered from samples collected in central and southwest Michigan in 2005.

In 2004, excessive rainfall occurred in the three asparagus growing regions during spear harvest. In the northwest region, the total rainfall during May 2004 was $246 \mathrm{~mm}$, which fell on 21 days. On four of these days, the rainfall was $>2.0 \mathrm{~cm}$, an amount established by Ristaino (43) as a saturation event for light soils. During the same period in central Michigan, rain occurred on 13 days (205 $\mathrm{mm}$ total), 1 day received rain $>2.0 \mathrm{~cm}$. In the southwest region, rain occurred on 16 days, producing a total of $100 \mathrm{~mm}$ of rain. No single rain event registered $>2.0 \mathrm{~cm}$ in a $24-\mathrm{h}$ period in the southwest region. The amount of rainfall registered during the 2005 growing season was very low. Rainfall totals of only 51, 33, and $34 \mathrm{~mm}$ were recorded in northwest, central, and southwest Michigan, respectively. These totals represented a fraction of the total rainfall recorded in the northwest $(21 \%)$, central $(16 \%)$, and southwest $(34 \%)$ growing regions in May 2004. In 2005, no rain events of $>2.0 \mathrm{~cm}$ in a $24-\mathrm{h}$ period were recorded in any of the three growing regions included in this study. 


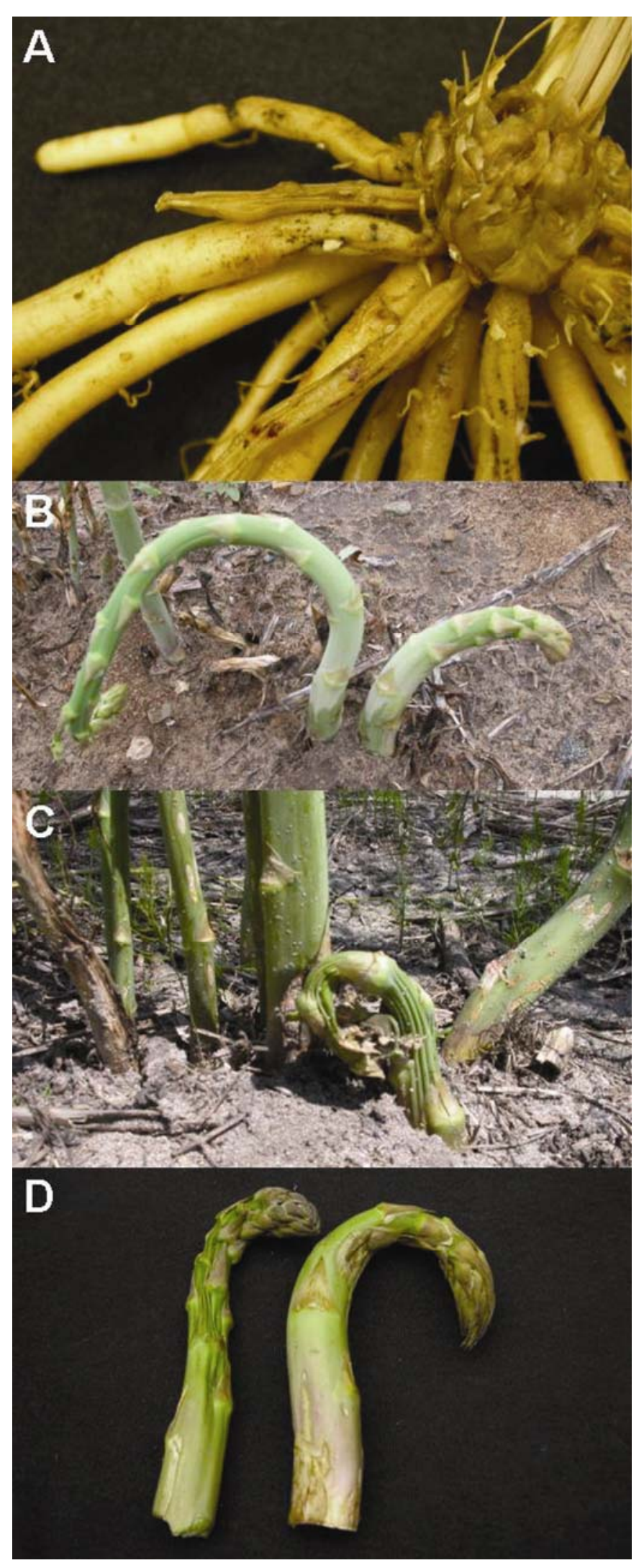

Fig. 1. Symptoms caused by Phytophthora sp. on asparagus. A, Infected storage roots become water-soaked and shrivel as the lesion expands. Root mass and vigor may be reduced. $\mathbf{B}$ and $\mathbf{C}$, Infected spears present soft, watersoaked lesions on shoots slightly above or below soil line. Lesions often shrivel, causing the spear to curve and eventually to collapse. D, Shriveled and distorted harvested spears.
Colony and spore morphology. Phytophthora sp. recovered from asparagus exhibited morphological traits attributed to $P$. megasperma $(12,46)$. Colonies of Phytophthora sp. on AR-V8 juice agar had a stellate to rosaceous growth pattern (Fig. 2E). Both sporangia and oospores were produced on AR-V8 juice agar with oospores more profusely produced than sporangia. Abundant, uniform, and long lasting sporangia, as well as uniform oospores, were produced on dilute V8 juice agar, but few sporangia were produced on V8 juice agar. Phytophthora isolates produced ovoid, obpyriform, nonpapillate, noncaducous sporangia (Fig. 2A) borne on simply- or sparingly-branched sporangiophores and/or on internal proliferation (Fig. 2D), after evacuation of zoospores (Fig. 2C). Isolates produced amphigynous oospores (Fig. 2B), and chlamydospores were not produced. Sporangia mean length $(n=50)$ ranged from 42 to $47 \mu \mathrm{m}$ and mean breadth from 23 to $40 \mu \mathrm{m}$. Oospores mean diameter $(n=50)$ ranged from 25 to $30 \mu \mathrm{m}$.

Effect of temperature on mycelial growth. Temperature had an effect on mycelial growth of the 46 Phytophthora isolates examined. When inoculated onto AR-V8 juice agar, all isolates grew when incubated at temperatures between 10 and $25^{\circ} \mathrm{C}$, with optimum growth at $25^{\circ} \mathrm{C}(P=0.0001)$ (Fig. 3). The average colony diameter after 3 days of mycelial growth at $25^{\circ} \mathrm{C}$ was $34 \mathrm{~mm}$. At 7 days after inoculation, the diameter of the majority of the isolates measured approximately $75 \mathrm{~mm}$, almost the entire diameter of the AR-V8 juice agar plate (Fig. 3). Sporangia and oospores were produced at temperatures between 10 and $25^{\circ} \mathrm{C}$ at 7 days after inoculation. Mycelial growth patterns were similar on both evaluation dates, and no growth was recorded on plates incubated at 5 and $30^{\circ} \mathrm{C}$ (Fig. 3).

Mefenoxam sensitivity. All isolates $(n=131)$ of Phytophthora sp. were highly sensitive to mefenoxam. On V8 juice agar with no mefenoxam, the average radial growth of the mycelium after 5 days was $42 \mathrm{~mm}$. On V8 juice agar amended with $100 \mathrm{ppm}$ mefenoxam all isolates failed to grow, indicating sensitivity to the fungicide (data not shown).

Pathogenicity on asparagus spears. A preliminary study (data not shown) showed that wounding of asparagus spear tissue was needed for disease development by Phytophthora sp. under laboratory conditions. Inoculation of wounded asparagus spears with the 115 Phytophthora isolates listed in Table 1 resulted in water soaking, spear shriveling, and collapse 7 days after inoculation. Regardless of the origin of isolates (geographic location of sample/plant tissue infected), there were no significant differences in overall average lesion length among isolates, although isolate SP112 resulted in slightly longer lesions $(62 \mathrm{~mm})$ than other isolates. Lesion length among the remaining 114 isolates was similar and ranged from 56 to $21 \mathrm{~mm}$, with $97 \%$ of isolates causing lesions that exceeded $30 \mathrm{~mm}$ in length. No lesions developed on uninoculated spears.

Pathogenicity on asparagus, soybean, alfalfa, and red clover seedlings. In the greenhouse, seedlings of both asparagus cultivars Jersey Giant and Mary Washington wilted 2 weeks after inoculation with Phytophthora isolate C009, and died between weeks 3 and 4 postinoculation. Asparagus seedlings remained healthy when inoculated with $P$. sojae, but the organism was reisolated from asparagus roots (Fig. 4). Phytophthora sp. from asparagus did not infect soybean seedlings, although the pathogen was reisolated from the roots following inoculation. Plant wilt and death were recorded at 1 and 3 weeks, respectively, after inoculation with the $P$. sojae isolate (Fig. 4). Neither Phytophthora sp. nor $P$. sojae caused significant disease to alfalfa and red clover seedlings, but each organism was recovered from the roots of inoculated plants. Control plants remained healthy throughout the experiment.

Pathogenicity on cucurbit fruits. Inoculation of fruits from five different cucurbits with 25 isolates of Phytophthora sp. from asparagus resulted primarily in water-soaked lesions on zucchini, 
water-soaked and necrotic lesions on yellow squash, and watersoaked lesions with some mycelial growth on slicing and pickling cucumbers. No lesions were observed on acorn squash or on any of the control fruits. The average lesion length on the fruits infected with the Phytophthora isolates ranged from 2.6 to $4.8 \mathrm{~cm}$. Due to similarities in pathogenicity of the Phytophthora isolates, results of just five representative isolates are presented (Table 2).

AFLP fingerprinting. AFLP analysis of 99 Phytophthora isolates recovered from asparagus in northwest and central Michigan in 2004 (86 isolates) and in northwest Michigan in 2005 (13 isolates) revealed identical fingerprints. Twelve clearly resolved fragments were present for each isolate using the Eco+AC/Mse+CAA primer combination (Fig. 5). There were no clearly resolved polymorphic fragments (Fig. 5). Based on these results, the different isolates are considered to be of one clonal lineage.

ITS sequencing and phylogenetic analysis. Because AFLP results indicated that the isolates were identical, one representative isolate from each year was selected for sequencing of the
ITS region. A representative sequence of the ITS region was deposited in GenBank (accession EF185089). The results of the BLASTn query (1) indicated that the Phytophthora sp. isolated from asparagus in Michigan has an exact match to Phytophthora sp. asparagus (e value $=0$, accession AF266796) described elsewhere (7). A phylogenetic analysis based on ITS sequences (using the six closest matches from the BLASTn search) supports the conclusion that this asparagus Phytophthora sp. is a distinct species and is not closely related to isolates considered to be $P$. megasperma (Fig. 6). Therefore, it is proposed that this new Phytophthora sp. be named P. asparagi. P. asparagi isolate SP326 has been deposited with the Cornell Plant Pathology Herbarium (CUP-67873) and registered with the MycoBank (MB511931).

\section{DISCUSSION}

The identification of spear and root rot caused by Phytophthora $\mathrm{sp}$. in the asparagus growing region of Michigan increases the risk faced by producers who were already concerned with Fusarium crown and root rot, a devastating soilborne disease caused by $F$.

TABLE 1. Characteristics of Phytophthora sp. isolates recovered from asparagus in Michigan in 2004 and 2005

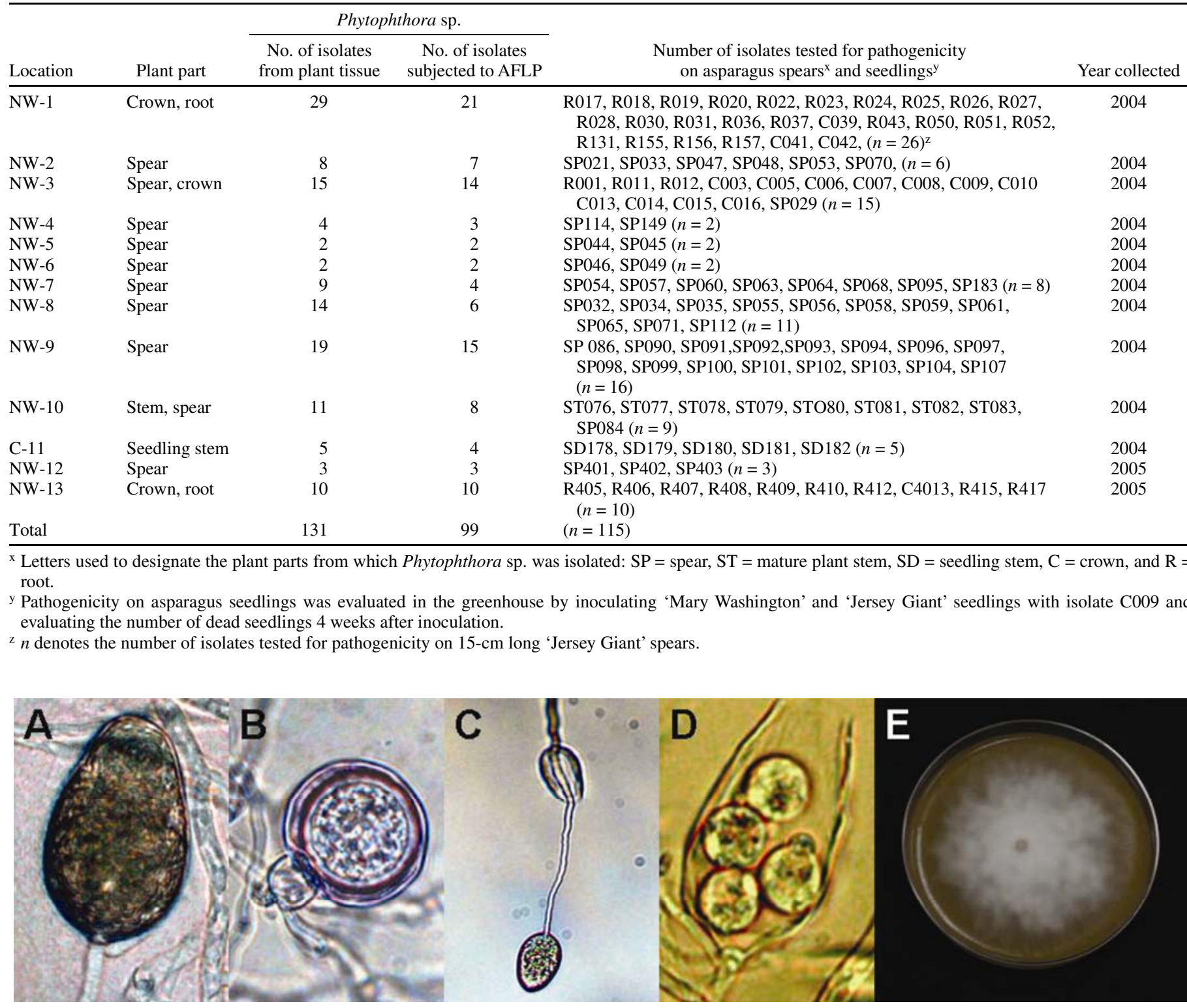

Fig. 2. Morphology of Phytophthora sp. isolated from asparagus on dilute V8 juice agar. A, Ovoid, nonpapillate, noncaducous sporangium with mean length of 42 to $47 \mu \mathrm{m}$ and mean breadth of 23 to $40 \mu \mathrm{m}$. B, Oospore with amphigynous antheridia with mean diameter of 25 to $30 \mu \mathrm{m}$. C, Sporangium produced by internal proliferation. D, Sporangium containing encysted zoospores. E, Colony morphology of Phytophthora sp. grown on V8 juice agar for 7 days at $25^{\circ} \mathrm{C}$. 
oxysporum f. sp. asparagi and $F$. proliferatum $(30,44)$. Phytophthora sp. and Fusarium spp. can reduce the lifespan of an asparagus production field (14).

Phytophthora isolates from asparagus were morphologically similar to $P$. megasperma. The finding that the ITS sequence for the Phytophthora sp. infecting asparagus in Michigan is identical to isolates of Phytophthora sp. recovered from asparagus in Europe and agave in Australia (10) suggests that this species has been widely dispersed and is not specific to asparagus. It would be helpful to obtain Phytophthora isolates from the European and New Zealand populations to determine if the fingerprint type is identical or varies. Isolates recovered in Michigan from different locations over 2 years were genetically homogeneous likely as a result of the self-fertilizing sexual stage. Inbreeding maintains homozygosity across the genome. This particular Phytophthora sp. produces large numbers of oospores in culture.

In May 2004, excessive rainfall during harvest in the northwest region of Michigan preceded the outbreak of Phytophthora spear and root rot. Multiple saturation events occurred in succession and did not allow adequate time for water to drain from the fields. Rain splashing moved infested soil onto emerging spears, resulting in water-soaked tissue and disease. In contrast, the southwest region of the state was relatively dry in 2004 with no saturation events and Phytophthora sp. was not readily recovered from asparagus. The drought conditions observed during the 2005 harvest season across the Michigan asparagus growing region inhibited the disease and relatively few symptomatic spears were observed.

Saturated soil conditions from rainfall or excessive irrigation have been implicated in the increase of Phytophthora root rot disease outbreaks of many perennial and annual crops $(33,38,41)$. Wet soil conditions stimulate the release of zoospores from sporangia, increasing inoculum levels. Phytophthora rot of asparagus in California was associated with a period of heavy and prolonged rainfall and the common practice of flooding certain asparagus production areas to prompt early plant growth (4). Falloon et al. (24) reported that more $P$. megasperma var. sojae isolates were recovered from asparagus in a year when rain totaled $300 \mathrm{~mm}$ during the harvest season, than in the following year which had only $77 \mathrm{~mm}$ of rain. Parra and Ristaino (41) reported rapid progress of root and crown rot of bell pepper (Capsicum annum) caused by $P$. capsici in fields after a single rainfall $>2 \mathrm{~cm}$ at a very low inoculum of 2 to 5 colony forming units (CFU)/g of soil. Plant-to-plant spread of $P$. capsici occurring with heavy rainfall episodes had a major impact on final disease incidence and on yields (41).

Our temperature study indicated that mycelial growth of Phytophthora sp. occurred between 10 and $25^{\circ} \mathrm{C}$, with the greatest growth at $25^{\circ} \mathrm{C}$ and no growth above $25^{\circ} \mathrm{C}$. This is comparable to

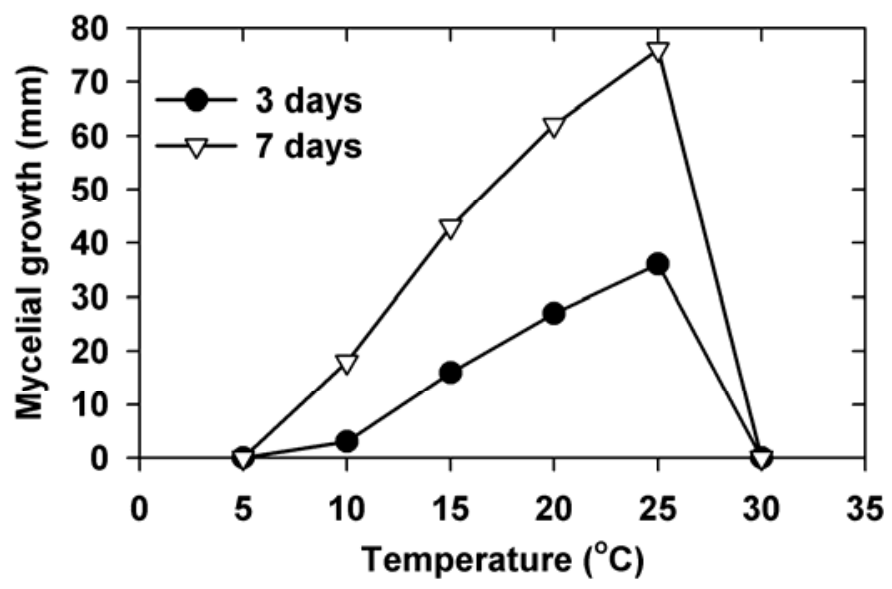

Fig. 3. Effect of temperature on mycelial growth of 46 isolates of Phytophthora sp. on AR-V8 juice agar 3 and 7 days after inoculation. the findings of Boesewinkel (6) who determined a temperature optimum of 20 to $22^{\circ} \mathrm{C}$ for mycelial growth of a Phytophthora sp. infecting asparagus in New Zealand. Falloon et al. (19) noted that high losses occurred in the early part of the asparagus harvest season after periods of heavy rainfall when soil temperatures were between 9 and $24^{\circ} \mathrm{C}$.

Wounding of asparagus plants may exacerbate Phytophthora spear rot disease. Blowing sand and soil particles may cause abrasions on the spears during rain storms and provide an avenue for infection. In the laboratory, wounding was necessary for disease development when testing for virulence of Phytophthora sp. on detached asparagus spears. Stomata serve as a point of entry for many pathogens and when spears are detached from plants, the stomata close, requiring wounding for some pathogens to cause infection. Lacy (34) reported that wounding of spears was needed in the laboratory for infection of asparagus spears by Stemphylium vesicarium to occur, while in the field wounding was not essential because stomata are open and facilitate infection by purple spot.

Spears are succulent, with high levels of soluble sugars, high water (90 to 92\%), and low fiber content. During our study, the pathogen was readily isolated from spears with water-soaked symptoms or from dormant crowns in storage. In contrast, the pathogen was rarely isolated from spears that lacked the watersoaked lesion but displayed a shepherd's crook symptom. Crown and storage root tissue is fibrous with less water and soluble sugars than spears $(9,37)$. It was difficult to obtain a Phytophthora isolate from this crown tissue associated with symptomatic or even dying fern. Our results are in agreement with those of Falloon and Grogan (23) who suggested that isolation from spears was the most reliable method to detect Phytophthora spp.

The fungicide mefenoxam is registered for use on asparagus and may be applied prior to the first cutting of the season to manage spear and crown rot. Mefenoxam and metalaxyl are phenylalamide fungicides used to manage disease caused by oomycetes. All isolates of Phytophthora spp. obtained from

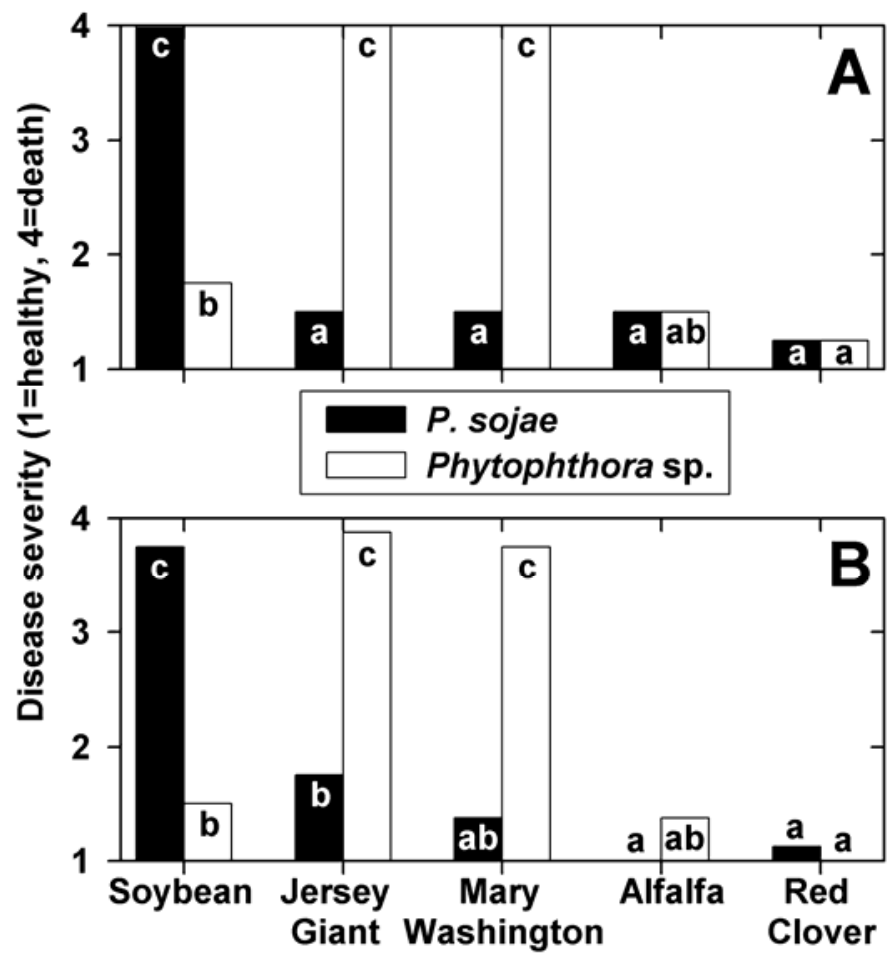

Fig. 4. A and B, Pathogenicity of Phytophthora sp. isolated from asparagus and $P$. sojae on asparagus 'Mary Washington' and 'Jersey Giant', soybean cultivar William, alfalfa, and red clover (unknown cultivars). Bars with a letter in common are not significantly different (Student-Newman-Keuls; $P=0.05$ ). 
Michigan asparagus were sensitive to $100 \mathrm{ppm}$ mefenoxam in vitro. An earlier field study in Michigan showed a significant reduction of Phytophthora symptoms (shepherd's crook) on asparagus fern when mefenoxam (Ridomil Gold 4EC, Syngenta) was periodically applied directly to crowns via drip irrigation (8). The beneficial effects of metalaxyl-based products were previously reported by Falloon et al. in New Zealand (22) and California (19). In both studies, fewer infected spears and increased yields were observed when metalaxyl was applied compared with an untreated infected plot. In addition, harvesting plots treated with metalaxyl started earlier with better quality of spears at the end of the harvest season compared with the control plot (19). Although promising, the use of mefenoxam-based products for management of Phytophthora spear and root rot of asparagus should be approached with caution, since resistance to mefenoxam by some Phytophthora spp. has been reported $(31,33,36,40)$. Further, the fungicide may offer limited protection when applied as a spray because the product may not reach the crown that may be located $38 \mathrm{~cm}$ or more below the surface.

The Phytophthora sp. affecting asparagus may be a source of inoculum for cucurbits also grown in this region of Michigan. To date, $P$. capsici has been the only Phytophthora isolated from cucurbits. In this study, Phytophthora isolates from asparagus infected and/or reproduced on cucumber, zucchini, and yellow squash fruits, although they did not cause extensive disease. Phytophthora sp. was isolated from the roots of inoculated but

TABLE 2. Lesion length $(\mathrm{cm})$ caused by inoculation of Phytophthora sp. isolates on fruits of five cucurbits

\begin{tabular}{lccccc}
\hline Isolate $^{\mathrm{x}}$ & Slicing cucumber & Pickling cucumber & Zucchini & Yellow squash & Acorn squash \\
\hline ST087y & $4.2 \mathrm{ab}^{\mathrm{z}}$ & $4.8 \mathrm{a}$ & $2.9 \mathrm{ab}$ & $4.3 \mathrm{a}$ & $0.0 \mathrm{a}$ \\
C039 & $4.8 \mathrm{a}$ & $5.4 \mathrm{a}$ & $2.8 \mathrm{ab}$ & $3.5 \mathrm{ab}$ & $0.0 \mathrm{a}$ \\
SP062 & $3.9 \mathrm{ab}$ & $3.8 \mathrm{~b}$ & $3.0 \mathrm{ab}$ & $4.7 \mathrm{a}$ & $0.0 \mathrm{a}$ \\
R037 & $4.9 \mathrm{a}$ & $3.7 \mathrm{~b}$ & $3.5 \mathrm{a}$ & $4.1 \mathrm{ab}$ & $0.0 \mathrm{a}$ \\
SD180 & $4.0 \mathrm{ab}$ & $4.3 \mathrm{ab}$ & $2.6 \mathrm{ab}$ & $4.0 \mathrm{ab}$ & $0.0 \mathrm{a}$ \\
\hline
\end{tabular}

${ }^{\mathrm{x}}$ Data represent the mean of two replicated trials in which three fruits were tested. Fruits were inoculated with the isolates, incubated at room temperature, and evaluated 7 days after inoculation.

${ }^{y}$ Five isolates are a representative sample of the 25 isolates evaluated on fruits of five cucurbit cultivars.

${ }^{\mathrm{z}}$ Numbers in a column followed by the same letter are not significantly different at $P=0.05$ (Student-Newman-Keuls).
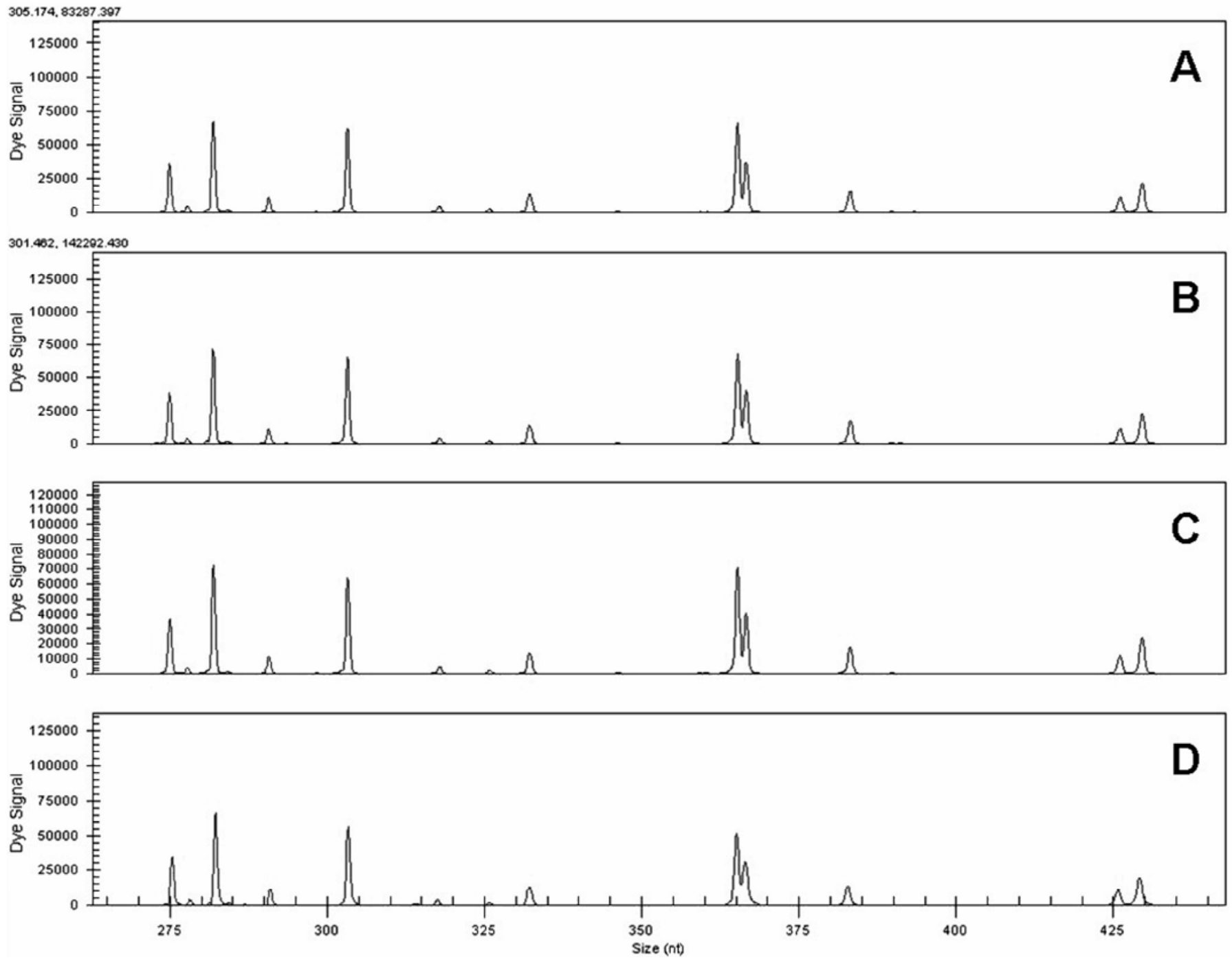

Fig. 5. Partial amplified fragment length polymorphism profiles for Phytophthora sp. isolates recovered from asparagus in A, northwest (2004), B, north central (2004), C, central (2004), and D, central (2005) Michigan. Sizes of the DNA fragments are indicated on the $x$ axis and intensity of fluorescent signal on the $y$ axis. 


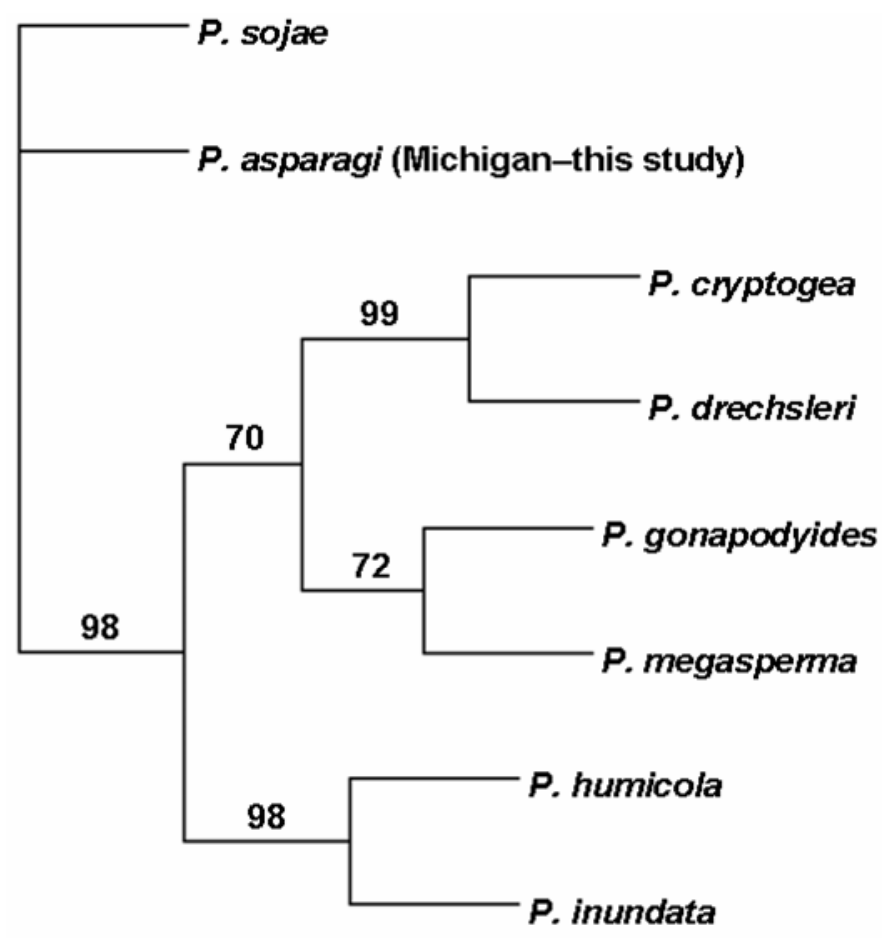

Fig. 6. Maximum likelihood phylogenetic tree based on internal transcribed spacer sequences. Phytophthora sp. isolate from this study showed identical location as $P$. asparagus described elsewhere. Bootstrap scores above nodes were calculated from analysis based on 1,000 replications.

asymptomatic soybean, alfalfa, and red clover plants growing in the greenhouse, suggesting that the organism is sustained in the roots and contributes to inoculum buildup. In Michigan, further studies are warranted to determine the potential host range of this Phytophthora sp. Such studies will assist growers in decisionmaking regarding land that has been cropped to asparagus and is being considered for other crop uses.

Current recommendations suggest that growers focus on methods to limit further spread of the pathogen. A key measure is to establish production fields from disease-free propagules. Oneyear-old dormant crowns dug from nursery fields are planted in production fields or are held in storage until field conditions are suitable for transplanting. When bulk boxes of asparagus crowns held in storage were sampled, Phytophthora was detected on $40 \%$ of the dormant crowns/roots. Historically, most Michigan crown nurseries have not fumigated and the nursery sites may have been cropped to asparagus previously, facilitating the movement of infected crowns and infested soils within and between fields, and between geographical regions. Further, until recently, the crowns were not subject to a visual inspection by Michigan Department of Agriculture unless they were to be shipped out of the state.

With the knowledge gained from this study, effective and reliable management strategies for Phytophthora spear and root rot can be formulated. Our results indicate that growers should consider practices that limit the negative effects of spear and root rot caused by Phytophthora sp., such as utilizing crowns grown in fumigated nurseries and/or direct seeding or transplanting greenhouse-produced seedlings into fumigated production fields. Judicious use of the fungicide, mefenoxam, may also be helpful (24).

\section{ACKNOWLEDGMENTS}

This research was funded by the USDA Cooperative State Research, Education and Extension Service Crops at Risk program award No. 200151100-11124, and by the Michigan Asparagus Research, Inc. We thank R. Duval and N. Althaver for their technical assistance, B. Cortright for assistance in collection of samples, and S. Windstam and S. Linderman for assistance in manuscript preparation.

\section{LITERATURE CITED}

1. Altschul, S. F., Madden, T. L., Schaffer, A. A., Zhang, J., Zhang, Z., Miller, W., and Lipman, D. J. 1997. Gapped BLAST and PSI-BLAST: A new generation of protein database search programs. Nucleic Acids Res. 25:3389-3402.

2. Anonymous. 2000. Crop profile for asparagus in California. USDA Regional IPM Center, Center Products, Crop Profiles. Online publication.

3. Anonymous. 2007. USDA National Agricultural Statistics Service, Michigan, State Level Data, Vegetables, Asparagus. Online publication.

4. Ark, P. A., and Barret, J. T. 1938. Phytophthora rot of asparagus in California. Phytopathology 28:754-756.

5. Benson, B., Souther, F., and Takatori, F. 1978. Establishing asparagus plantations with seedling transplants. Calif. Agric. 32:10-11.

6. Boesewinkel, H. J. 1974. Phytophthora on asparagus in New Zealand. Plant Dis. Rep. 58:525-529.

7. Cooke, D. E. L., Drenth, A., Duncan, J. M., Wagels, G., and Brasier, C. M. 2000. Molecular phylogeny of Phytophthora and related oomycetes. Fungal Genet. Biol. 30:17-32.

8. Counts, J. W., and Hausbeck, M. K. 2007. Strategies for managing Fusarium crown and root rot on asparagus. Proc. XI International Asparagus Symposium. Acta Hort. (ISHS) 776:167-174.

9. Culpepper, C. W., and Moon, H. H. 1939. Changes in the composition and rate of growth along the developing stem of asparagus. Plant Physiol. 14:677-698.

10. Cunnington, J. H., de Alwis, S., Pascoe, I. A., and Symes, P. 2005. The 'asparagus' Phytophthora infecting members of the Agavaceae at the Royal Botanic Gardens, Melbourne, Australas. Plant Pathol. 34:413-414.

11. Damicone, J. P., Cooley, D. R., and Manning, W. J. 1981. Benomyl in acetone eradicates Fusarium moniliforme and Fusarium oxysporum from asparagus seed. Plant Dis. 65:892-893.

12. Drechsler, C. 1931. A crown rot of hollyhocks caused by Phytophthora megasperma $\mathrm{n}$. sp. J. Wash. Acad. Sci. 21:513-526.

13. Drost, D. T. 1977. Asparagus. Pages 621-649 in: The Physiology of Vegetable Crops. H. C. Wien, ed. CAB International, New York.

14. Elmer, W. H. 2001. The economically important diseases of asparagus in the U.S. Plant Health Progress. Online publication doi:10.1094/PHP2001-0521-01-RV.

15. Erwin, D. C., and Ribeiro, O. K. 1996. Phytophthora Diseases Worldwide. The American Phytopathological Society, St. Paul, MN.

16. Falloon, P. G. 1982. The need for breeding asparagus in New Zealand. N.Z. J. Exp. Agric. 10:101-109.

17. Falloon, P. G. 1982. Baiting, pathogenicity and distribution of Phytophthora megasperma var. sojae in New Zealand asparagus soils. N.Z. J. Agric. Res. 25:425-429.

18. Falloon, P. G. 1986. A method for screening asparagus (Asparagus officinalis L.) seedlings for resistance to Phytophthora rot. Pages 220-227 in: Proc. of the 6th Int. Asparagus Symposium. Eucarpia Veg. Sect., Guelph, Canada.

19. Falloon, P. G., Falloon, L. M., Benson, B. L., and Grogan, R. G. 1986. Effect of Phytophthora megasperma var. sojae on yield of Asparagus officinalis. Plant Dis. 70:15-19.

20. Falloon, P. G., Falloon, L. M., Mullen, R. J., Benson, B. L., and Grogan, R. G. 1983. Effect of Phytophthora spear rot on asparagus yield. Calif. Agric. 37:16-17.

21. Falloon, P. G., and Fraser, H. A. 1991. Control of establishment failures in asparagus (Asparagus officinalis) caused by Phytophthora rot. New Zeal. J. Crop Hort. 19:47-52.

22. Falloon, P. G., Greathead, A. S., Mullen, R. J., Benson, B. L., and Grogan, R. G. 1991. Individual and combined effects of flooding, Phytophthora rot, and metalaxyl on asparagus establishment. Plant Dis. 75:514-518.

23. Falloon, P. G., and Grogan, R. G. 1988. Isolation, distribution, pathogenicity and identification of Phytophthora spp. on asparagus in California. Plant Dis. 72:495-497.

24. Falloon, P. G., Mullen, R. J., Benson, B. L., and Grogan, R. G. 1985. Control of Phytophthora rot with metalaxyl in established asparagus. Plant Dis. 69:921-923.

25. Felsenstein, J. 1985. Confidence limits on phylogenies: An approach using the bootstrap. Evolution 39:783-791.

26. Förster, H., and Coffey, M. D. 1993. Molecular taxonomy of Phytophthora megasperma based on mitochondrial and nuclear DNA polymorphisms. Mycol. Res. 97:1101-1112.

27. Förster, H., Cummings, M. P., and Coffey, M. D. 1999. Phylogenetic relationships of Phytophthora species based on ribosomal ITS DNA sequence analysis with emphasis on Waterhouse groups V and VI. Mycol. Res. 104:1055-1061. 
28. Godfrey, S. A. C., and Silby, M. W. 2000. Biological control of Phytophthora megasperma var. sojae, causal agent of Phytophthora rot of asparagus, by Pseudomonas aureofaciens PA 147-2: A preliminary field trial. N.Z. J. Crop Hort. 28:97-103.

29. Habera, L., Smith, L., Donahoo, R., and Lamour, K. H. 2004. Use of a single primer to fluorescently label selective amplified fragment length polymorphism reactions. Biotechniques 37:902-904.

30. Hansen, E. M., and Maxwell, D. P. C. 1991. Species of Phytophthora megasperma complex. Mycologia 83:376-381.

31. Hausbeck, M. K., and Lamour, K. H. 2004. Phytophthora capsici on vegetable crops: Research progress and management challenges. Plant Dis. 88:1292-1303.

32. Hibbett, D. S. 1992. Ribosomal RNA and fungal systematics. T. Mycol. Soc. Jpn. 33:533-556.

33. Hwang, J., and Benson, D. M. 2005. Identification, mefenoxam sensitivity and compatibility type of Phytophthora spp. attacking floriculture crops in North Carolina. Plant Dis. 89:185-190.

34. Lacy, M. L. 1982. Purple spot: A new disease of young asparagus spears caused by Stemphylium vesicarium. Plant Dis. 66:1198-1200.

35. Lamour, K. H., and Finley, L. 2006. A strategy for recovering high quality genomic DNA from a large number of Phytophthora isolates. Mycologia 98:514-517.

36. Lamour, K. H., and Hausbeck, M. K. 2000. Mefenoxam insensitivity and sexual stages of Phytophthora capsici in Michigan cucurbit fields. Phytopathology 90:396-400.

37. Lill, R. E., King, G. A., and O’Donoghue, E. M. 1991. Physiological changes in asparagus spears immediately after harvest. Sci. Hortic. 44:191-199.

38. MacDonald, J. D., and Dunway, J. M. 1978. Influence of the matric and osmotic components of water potential and zoospore discharge in Phytophthora. Phytopathology 68:751-757.

39. Molot, P. 1962. Les maladies cryptogamyques de l'asparge. Rev. Zool. Agric. Pathol. 61:71-76.

40. Oudemans, P. V. 1999. Phytophthora species associated with cranberry root rot and surface irrigation water in New Jersey. Plant Dis. 83:251-258.

41. Parra, G., and Ristaino, J. B. 2001. Resistance to mefenoxam and metalaxyl among field isolates of Phytophthora capsici causing Phytophthora blight of bell pepper. Plant Dis. 85:1069-1075.

42. Posada, D., and Crandall, K. 1998. MODELTEST: Testing the model of DNA substitution. Bioinformatics 14:817-818.

43. Ristaino, J. B. 1991. Influence of rainfall, drip irrigation and inoculum density on the development of Phytophthora root and crown rot epidemics and yield in bell pepper. Phytopathology 81:922-929.

44. Salas, B., Stack, R. W., Secor, G. A., and Gudmestad, N. C. 2000. The effect of wounding, temperature, and inoculum on the development of pink rot of potatoes caused by Phytophthora erythroseptica. Plant Dis. 84:1327-1333.

45. Saude, C., Hausbeck, M. K., Hurtado-Gonzalez, O., and Lamour, K. H. 2005. Detection of a Phytophthora sp. causing asparagus spear and root rot in Michigan. Plant Dis. 89:1011.

46. Stamps, D. J., Waterhouse, G. M., Newhook, F. J., and Hall, G. S. 1990 Revised tabular key to species of Phytophthora. Mycol. Pap. No. 162. Mycological Institute, CAB International, Wallingford, UK.

47. Swofford, D. L. 2002. PAUP: 4.0 Phylogenetic Analysis Using Parsimony (and Other Methods). v. 4. Sinauer Associates, Sunderland, MA.

48. Thompson, J. D., Higgins, D. G., and Gibson, T. J. 1994. CLUSTAL W: Improving the sensitivity of multiple sequence alignment through sequence weighting, position-specific gap penalties and weight matrix choice. Nucleic Acids Res. 22:4673-4680.

49. Vos, P. E., Hogers, R., Bleeker, M., Reijans, M., van der Lee, T., Hornes, M., Frijters, A., Pot, J., Pelemen, J., Kuiper, M., and Zabeau, M. 1995. AFLP: A new technique for DNA fingerprinting. Nucleic Acids Res. 23:4407-4414.

50. Vujanovic, V., Hamel, C., Jabaji-Hare, S., and St-Amaud, M. 2003. First report of root rot on asparagus caused by Phytophthora megasperma in Canada. Plant Dis. 87:447.

51. Waterhouse, G. M., and Waterston, J. M. 1931. Phytophthora megasperma Drechs. J. Wash. Acad. Sci. 21:525.

52. White, T. J., Bruns, T., Lee, S., and Taylor, J. 1990. Amplification and direct sequencing of fungal ribosomal RNA genes for phylogenetics. Pages 315-322 in: PCR Protocols: A Guide to Methods and Applications, M. A. Innis, D. H. Gelfand, J. J. Sninsky, and T. J. White, eds. Academic Press, San Diego. 